\title{
THE EFFECT OF SEMANTIC FEATURE ANALYSIS ON STUDENTS' VOCABULARY ACHIEVEMENT AT THE SECOND GRADE STUDENTS OF SMPN 14 KENDARI
}

\author{
Martha Yunita Mahaluby \\ Halu Oleo University
}

Email: marthayunita20@gmail.com

\begin{abstract}
Vocabulary becomes the main problem that encountered by the students in SMP Negeri 14 Kendari. Less motivation and interest are factors that affect students in learning vocabulary. The research question of this study was "Is there any significant effect of semantic feature analysis on students' vocabulary achievement at the second grade students of SMP Negeri 14 Kendari?" The objective of this study was to find out whether semantic feature analysis has an effect on students' vocabulary achievement at the second grade students of SMP Negeri 14 Kendari. The population of this study was all students at second grade of SMP Negeri 14 Kendari who registered on second semester in academic year $2017 / 2018$ with the total number of students' were 205 students. The samples of this study were all students at class VIII. 2 with total number of students are 30 and it taken by using simple random sampling. The instrument of this study was vocabulary test which consisted of 25 items ( 5 items matching with the synonym, 10 items matching with the meaning, 5 items complete the sentences and 5 items fill in the blank test). They were administered into two groups as the pre test and post test. The researcher used Paired Sample T-test in SPSS 16 to analyze the result of the research whether there is a significant effect of semantic feature analysis on students' vocabulary achievement after analyzed the normality of the data in experiment class. Based on the analysis result of pre-test and post-test through SPSS in form of test, it found that the probability (Sig. 1-tailed) was

$0.000(\rho<0.05)$ and the calculation of $t_{\text {count }}(10.070)$ was higher than $t_{\text {table }}(1.699)$ in the level of significance $0.05, \mathrm{df}=29$. It indicated that null hypothesis $\left(\mathrm{H}_{0}\right)$ was totally rejected and the alternative hypothesis $\left(\mathrm{H}_{1}\right)$ was completely accepted. Therefore, it can be concluded that there is enough evidence to claim that
\end{abstract}


semantic feature analysis strategy has significant effect on students' vocabulary achievement at the second grade students of SMP Negeri 14 Kendari.

\section{Keyword: Vocabulary, Semantic Feature Analysis}

\section{INTRODUCTION}

Vocabulary is one of important components of English Language and it is an integrated skill in English, because of that vocabulary considered as an important element to master the four skills in English. According to Laufer in Somayeh (2012:164), "vocabulary is the most important aspect in any particular language". Vocabulary is the aspect that has an important role in learning English. Knowing about vocabulary will make us able to read, write, speak and listen to the language. Linse (2005) said that, vocabulary is the collection of words that individual knows. Moreover, according to Nunan (1999) that teaching vocabulary is the most important aspect of language development. Based on those statements previously, it can be conclude that the mastering of vocabulary is very important for English learners. Thornbury (2002) said without grammar very little can be conveyed, without vocabulary nothing can be conveyed. Students cannot convey their meaning and will not understand by other people if they have not enough vocabulary. They also cannot communicate effectively if they have limit vocabulary.

Quirck (1987:117) stated that "vocabulary is a list of words with their meaning glossary, sum up words used in language or in particular book or branch of science etc by particular person, class, profession, etc". Moreover, Ur (1996) said that vocabulary is a group of word that is used to teach a foreign language. Based on that explanation, students must have a lot of vocabulary. Vocabulary is a word in language that is used to communicate. Vocabulary also is an aspect that is used since English language itself is decided to become a vital language that can be used to all people or since the government determined English as an international language. Therefore, knowing vocabulary is a crucial think to know and master.

According to Scrivener (2005) that in learning processes it will more useful if the learners work by themselves or their partner about a material from teacher rather than they hear many theories from the teacher. Those statements previously explain if teacher should choose appropriate technique to make the students can be more active in the class activities than their teacher. Moreover, the explanation technique would make students' motivation to study is low because the habitual technique that teacher's use is not make students involve in the process of teaching and learning but only hear the explanation. It can be conclude that students' motivation become the main key of the successful of teaching and learning. Those statement is supported by Spratt (2005:38) argued that "motivation is very important in language learning, it makes learning successful". Therefore, the using of appropriate technique in the classroom is very important to prepare where the students can enjoy the activities and make their motivation to study increase. 
Taylor (2009:9) said that "semantic feature analysis can help students to improve their vocabulary and categorization skills, understand relationships among words, relate their background knowledge to new words, and expand retain content area vocabulary and concepts". Moreover, Marilyn (2010) stated that semantic feature analysis is a strategy that can be used to organize visually new concepts and analysis can help students to increase their vocabularies and be a good strategy for students to increase their vocabulary achievement. Students can engage in teaching and learning process because semantic feature analysis offers activities that the students should become independent learners. They should use their own thinking to relate a key word to the feature of the grid. In the process, students will try to connect their schemata to the language so that there is a thinking process that makes them learn the language by themselves or discuss it with their partner.

According to Michael and Nascy (1987:29) pointed out "semantic is a meaning, feature is an attribute or part of the key word, and analysis is the way of describing something". In this study, researcher believes that semantic feature analysis is an appropriate technique to teach vocabulary and make the students can learn the words enjoy and can improve their vocabulary achievement. Those statements are support by Taylor (2009:5) defined that "Semantic feature analysis can help students to improve their vocabulary and categorization skills, understand relationships among words, relate their background knowledge to new words, and expand and retain content area vocabulary and concepts".

\subsection{Research Question}

In this study, the researcher formulate a research question as follows: "is there any significant effect of semantic feature analysis on students' vocabulary achievement at the second grade students of SMP Negeri 14 Kendari?"

\subsection{Objective of the Study}

The objective of this research was to find out whether semantic feature analysis had an effect on students vocabulary achievement.

\subsection{Significance of the Study}

This study was to help the English teacher as an information source for them in increasing their teaching improvement particularly teaching vocabulary, and also it helped students in mastering vocabulary by introducing semantic feature analysis as a good strategy.

\subsection{Scope of the Study}

The study investigated the students vocabulary achievement at the second grade students of SMP Negeri 14 Kendari by using Semantic Feature Analysis. In this study researcher just limited on two word classes they are noun (kinds of 
animal and plants, such as: giraffe, ants, bats, cucumber, potato, bark, etc.) and adjective (such as: wild, tall, beautiful, sweet, etc.) because those are always appear in students' activity of their book.

\section{LITERATURE REVIEW}

In mastering vocabulary, we should not only know about the vocabulary itself but also all its component including types of the vocabulary. According to Shaw and De Vet (1990) defined that there are two types of vocabulary namely: the first is active vocabulary; words that students should understand and use them any time. In teaching, students will see how the words are used and the using of the words itself tend to giving example and asking question. The second is passive vocabulary; words that students just need to understand (example: when reading a text) where they will not need to use themselves. The using of the words is suggested to present with a simple example that do not need much time.

According to Edward (1997) that in language teaching vocabulary becomes the important factor that should be master the students should learn the words continually based on their needs. Moreover, Esmaeel (2009:3) said that "in recent years, the teaching of vocabulary has assumed its rightful place as a fundamentally important aspect of language development". Based on the experts' explanation previously, in can be concluded that the teaching vocabulary is the basic factor for students to make them can learn a language.

Svenconis (2006) pointed out that, teaching of foreign language vocabulary is an essential part of the curriculum of many schools and will never change in the future. Based on the statement earlier, it shows that vocabulary is really an important aspect that students should learn first. To teach the vocabulary itself, teacher should know what the students' need in their level. Teacher should be able to determine the words as their target that can be remembered by students for a long time that is why teacher should know some strategy to make the students can easy learn the words. There are several strategies that teacher can use in teaching vocabulary as Gairns and Redman (1986) stated that, there are two strategies for teacher they are visual and verbal. Visual strategy can be used by teacher based on the several parts of the visual items such as picture, real object or gesture. Whereas, verbal strategy also has items to teach vocabulary such as definition, illustrative sentence, synonym and antonyms, scales, explanation, translations. Those are the strategies that expert believe can help teacher to make students learn vocabulary and also to make students can remember the word for a long time.

According to Michael and Nascy (1987:29) pointed out "semantic is a meaning, feature is an attribute or part of the key word, and analysis is the way of describing something". In this study, researcher believes that semantic feature analysis is an appropriate technique to teach vocabulary and make the students can learn the words enjoy and can improve their vocabulary achievement. Those statements are support by Taylor (2009:5) defined that "Semantic feature analysis can help students to improve their vocabulary and categorization skills, understand relationships among words, relate their background knowledge to new words, and expand and retain content area vocabulary and concepts". 
In semantic feature analysis students can learn not only for a single word but also the relationship of the all words, it made them easy to know the meaning of the words. Semantic feature analysis made the students more active in the activities of classroom because teacher was provide time for students to relate between the key word and the feature of the grid by themselves and then there was a discussion time with their classmate to find out the reason why they connect the key word with the feature. The students was became independent students that had responsibility to be more active in doing task so that semantic feature analysis can be an appropriate technique to teach vocabulary. In line with those statement, according to Paulsen (2004) described that, semantic feature analysis is as a useful way to teach vocabulary and the students' prior knowledge or schemata will be more working on when they do the task, the process will help students to recognize the words because the students learn by themselves to finish the task based on their ideas indirectly and the teacher just provide a key answer for them and do an evaluation.

\section{METHOD}

Design of this research used pre-experimental design by using one class that is given pre-test and post-test after having a treatment. In this research, firstly, one class was given pre-test. Then, a treatment was given still in the same class. Finally, post-test also was given to know whether or not there is an effect after giving that treatment. This is intended to describe the effectiveness of the students' vocabulary achievement through semantic feature analysis strategy by comparing the result of pre-test and post-test from one class.

\subsection{Population of the Study}

The population of the study was all of the students at the second grade of SMPN 14 Kendari who were registered on second semester in academic year 2017/2018. The total of the population are 205 students with 6 parallel classes which consist of 30 to 36 students on each class.

\subsection{Sample of the Study}

The sample of this study was taken by using simple random sampling. It means that the sample of population was taken by lottery all the population and the result of that lottery being the sample of the research. Simple random sampling is a subset of a statistical population in which each member of the subset has an equal probability of being chosen (Sugiyono, 2008). In this case, the sample of this research as the result of the lottery was class VIII.2 that consists of 30 students.

\subsection{Instrument of the Study}

The instrument of this study was vocabulary test, which consist of matching with the synonym, matching with the meaning, complete the sentences and fill in the blank. The test was made by the researcher based on the book that is used in that school. The total number of the pre and post test were 25 items where the items test represented each target words of the material in each meeting. The test 
itself used to see the students' achievement about the mastery of the vocabulary target that was provided by researcher.

\subsubsection{Validity of the Test}

The researcher checked the validity of the test previously. In this study, for analyzing the validity of instruments, the researcher used I-CVI (Item-Content Validity Index) and S-CVI (Scale-Content Validity Index). In analyzing the test by using I/S-CVI, the researcher needed at least three judges who judge the validity of test items (De Vellis, 2003). Therefore, the researcher asked three senior English teachers who had more than 5 years teaching experiences as the judges. They evaluated each item of the test before being piloted. Each judge gave 1 (one) point for the relevant item. All items were calculated by using I-CVI formula. If the score was in range $0.80-1$, it means that the item was valid. The formula of ICVI as follows:

$$
\mathrm{I}-\mathrm{CVI}=\frac{\text { TotalPoints }}{\text { ThenumberofJudges }}
$$

Table 1. Pilot Study of Validity Test of Each Item

\begin{tabular}{|c|c|c|}
\hline $\begin{array}{c}\text { Ite } \\
\mathbf{m}\end{array}$ & Score & Interpretation \\
\hline 1 & 1 & Valid \\
\hline 2 & 0,66 & Valid \\
\hline 3 & 1 & Valid \\
\hline 4 & 1 & Valid \\
\hline 5 & 0,33 & Invalid \\
\hline 6 & 0 & Invalid \\
\hline 7 & 1 & Valid \\
\hline 8 & 1 & Valid \\
\hline 9 & 0,33 & Invalid \\
\hline 10 & 0 & Invalid \\
\hline 11 & 1 & Valid \\
\hline 12 & 1 & Valid \\
\hline 13 & 1 & Valid \\
\hline 14 & 0 & Invalid \\
\hline 15 & 0,33 & Invalid \\
\hline 16 & 1 & Valid \\
\hline 17 & 1 & Valid \\
\hline 18 & 1 & Valid \\
\hline 19 & 0,66 & Valid \\
\hline 20 & 1 & Valid \\
\hline
\end{tabular}




\begin{tabular}{|c|c|c|}
\hline 21 & 1 & Valid \\
\hline 22 & 1 & Valid \\
\hline 23 & 0,33 & Invalid \\
\hline 24 & 1 & Valid \\
\hline 25 & 1 & Valid \\
\hline 26 & 1 & Valid \\
\hline 27 & 1 & Valid \\
\hline 28 & 1 & Valid \\
\hline 29 & 1 & Valid \\
\hline 30 & 1 & Valid \\
\hline 31 & 1 & Valid \\
\hline 32 & 1 & Valid \\
\hline 33 & 1 & Valid \\
\hline 34 & 1 & Valid \\
\hline 35 & 0 & Invalid \\
\hline 36 & 1 & Valid \\
\hline 37 & 1 & Valid \\
\hline 38 & 1 & Valid \\
\hline 39 & 1 & Valid \\
\hline 40 & 1 & Valid \\
\hline
\end{tabular}

From the result in table 4.1 above, there are 8 (eight) items were invalid. Then the result of each item researcher used to determine whether or not the entire test item was valid. The formula of S-CVI as follows:

$$
\begin{aligned}
\text { S-CVI } & =\frac{\text { the total score of } I-C V I \text { each item }}{\text { total items }} \\
& =\frac{32,64}{40} \\
& =0.816
\end{aligned}
$$

The score of S-CVI of the test was 0.816 while the entire item was valid if the score was in range $0,80-1$. It can be concluded that the entire item of the test was valid because the score was in range $0,80-1$. Then for the invalid items, the researcher deleted it in the items of the vocabulary test, researcher used only 25 items. 


\subsubsection{Reliability of the Test}

Reliability of the test was calculated using Cronbach's Alpha by means of SPSS 16 for windows to check whether the test was reliable or not. The following is the result of statistical computation reliability test.

Table 2. The Result of Reliability Test

\section{Reliability Statistics}

\begin{tabular}{|c|c|}
\hline Cronbach's Alpha & N of Items \\
\hline .550 & 25 \\
\hline
\end{tabular}

The table previously shows that the reliability statistics of the test was 0,550 . Based on the $r$ table Coefficient Correlation (Reliability), the value 0,550 was in moderate level. This could be concluded that the test was applicable for pre test and post test in this study.

\subsection{Procedures of the Study}

Johnson, D. D. \& Pearson, P. D. (1984:4) stated that there are seven steps the instructional sequence of semantic feature analysis in teaching vocabulary as follows:

Step 1. Select a category that relates to a topic to study or a reading selection. Select key words relate to the topic.

Step 2. Make a chart with a topic heading at the top, key words list down the side, and columns across the page. Head some of the columns with terms that represent features share by some of the words.

Step 3. Have the students place a plus or minus sign in each column across from each words, depending on whether or not the word has the feature heading the column. A question mark maybe use if the student not know.

Step 4. Have the students discuss each word, tell why they choose a plus or minus, and explain how the word is similar to or different from the other words on the list. (This activity to make students can recognize the words that will appear in the next step).

Step 5. Provide the plan lesson (e.g., lecture, reading, video, pictures, body).

Step 6. Based on the information in the lesson, have the students change the signs in the matrix or fill in those that have question marks or leave blank.

Step 7. Guide a discussion about the relationship between the words and features. During the discussion, use a class chart shown on an overhead projector or drawn o the board and fill in the signs that have attained group consensus.

In short, the instruction process in construction a chart is sequence. It is similar to try the students to use their systematic work of thinking and relating the words. 
To find out the result of this study, the researcher conducted a try out to pilot class that had been applied in class VIII.3 on April, 27 ${ }^{\text {th }}$ 2018. Piloted the study must done in different class to measure the validity and reliability of the instrument and also the allocation time of the SFA strategy before applied it on experiment class. After conducted the try out to the pilot class, the researcher conducted a pre-test to the students of class VIII.2 as the experiment class of this study and it was done on April, $28^{\text {th }}$ 2018, the pre test was vocabulary test. The researcher used a pre-test because it had benefit that was to determine the baseline of each student before giving them the treatments. In this study, the treatments was giving on three meetings based on the topic of learning (descriptive and recount text) of the lesson plan. The Semantic Feature Analysis strategy was applied in this treatment, the procedures of SFA was same on every meetings, the differences was only the reading text that researcher used, it means that on every meetings researcher used different reading text to students so that they could have new vocabulary every meetings. The first treatment was giving on April $30^{\text {th }}$ 2018, the second meeting was done on May 02 2018 and the third meeting was done on May $03^{\text {rd }} 2018$. After all treatments was done, the researcher conducted the post-test to find out the result whether there is a significant effect or not on students' vocabulary achievement by using Semantic Feature Analysis strategy. The post-test was done on May, $05^{\text {th }} 2018$, the content and form of the post-test was same with the pre-test where students answered the vocabulary test.

\section{FINDINGS AND DISCUSSION OF THE STUDY}

\subsection{Findings of the Study}

The following table shows the result of paired sample t-test analysis on students' score on pre and post-test.

Table 4.1 Analysis Result of Pre and Post-Test

Paired Samples Statistics

\begin{tabular}{|r|r|r|r|rr|}
\hline & Mean & \multicolumn{1}{|c|}{$\mathrm{N}$} & \multicolumn{1}{c|}{ Stut. } & \multicolumn{2}{|c|}{ Std. Error Mean } \\
\hline Pair 1 & Pretest & 29.1333 & 30 & 15.23773 & 2.78202 \\
& Posttest & 64.0000 & 30 & 18.64366 & 3.40385 \\
\hline
\end{tabular}


Paired Samples Test

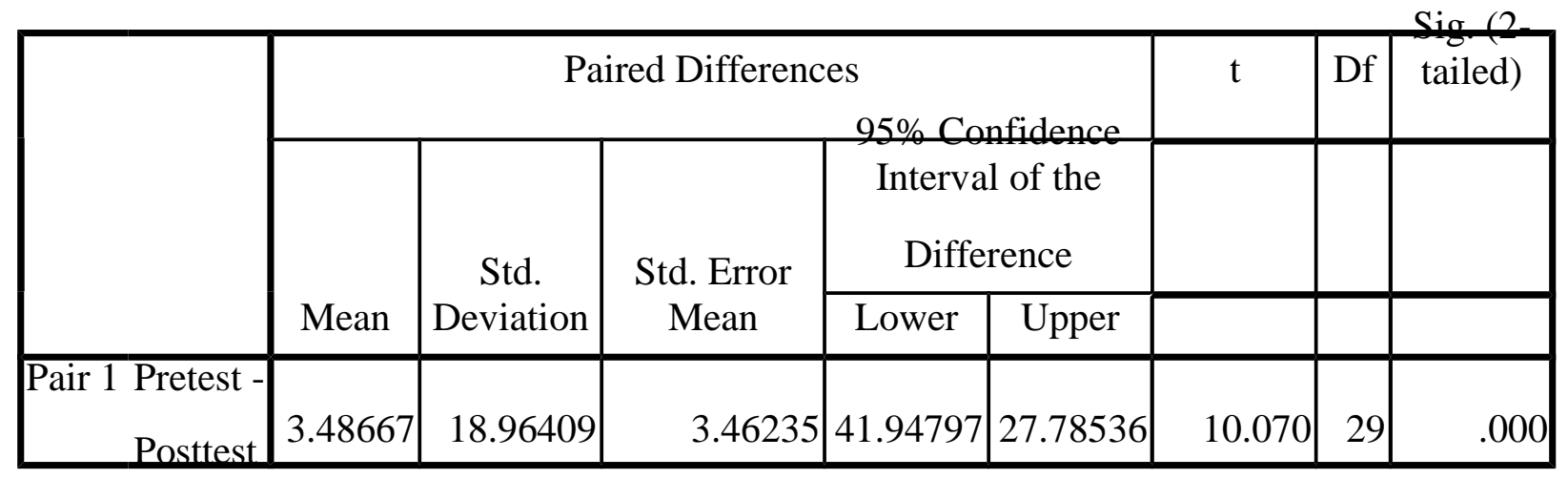

The computation result of the normality of distribution of pre and post tests indicated that the data of pre and post-test were normally distributed. Therefore, paired sample t-test should be used to find out whether there was a significant effect of semantic feature analysis teaching strategy implementation on students' vocabulary achievement or not. The first table shows that mean of pre-test is 29.1333 with standard deviation is 15.23773 and the mean of post-test score is 64.0000 with standard deviation is 18.64366 . In the second table the probability value (Sig. 2-tailed) is 0.000 .

This research used directional hypothesis in which the researcher believes that there was a positive significant effect of semantic feature analysis strategy on students' vocabulary achievement. The directional hypothesis as following:

$\mathrm{H}_{0}$ : Semantic Feature Analysis Strategy does not improve students' vocabulary achievement.

$\mathrm{H}_{1}$ : Semantic Feature Analysis Strategy improves students' vocabulary achievement.

Furthermore, based on those two directional hypotheses, to prove whether hypothesis $\mathrm{H}_{0}$ or $\mathrm{H}_{1}$ would be accepted or rejected, the probability value (Sig. 1tailed) should be used. It means the probability value (Sig. 2-tailed) of the paired sample t-test must be divided by 2 to obtain the probability value (Sig. 1-tailed). Then 0.000 (Sig. 2-tailed) was divided by 2 equaled 0.000 .

The probability value (Sig. 1-tailed) was 0.000 and $t_{\text {count }}(10.070)$ was higher than $\mathrm{t}_{\text {table }}$ at the 0.05 level of significance to the line $\mathrm{df}=29$ (1.699).

$\mathrm{H}_{0}$ is accepted if the probability value is higher than the alpha or the level of significance $(p>0.05)$ and rejected if the probability value is less than or equal to the level of significance $(\mathrm{p} \leq 0.05)$. In this case the probability value is less than the level of significance so it can be concluded that $\mathrm{H}_{0}$ is rejected and $\mathrm{H}_{1}$ is accepted. In other words, semantic feature analysis strategy gave positive effect on students' vocabulary achievement at the second grades of Junior High School 14 Kendari.

\subsection{Discussion}


These results suggested that teaching vocabulary through semantic feature analysis strategy had a positive significant effect on students' vocabulary achievement because in semantic feature analysis students can learn not only for a single word but also the relationship of the all words, it made them easy to know the meaning of the words. As supported by Taylor (2009:5) said that "semantic feature analysis can help students to improve their vocabulary and categorization skills, understand relationship among words, relate their background knowledge to new words, and expand retain content area vocabulary concepts". Semantic feature analysis made the students more active in the activities of classroom because teacher provided time for students to relate between the key word and the feature of the grid by themselves and then there was an analyze step that students had made sentences from the chart, that step showed their understanding about the relationship of the words in the SFA chart.

The students became independent students that had responsibility to be more active in doing task so that semantic feature analysis could be an appropriate technique to teach vocabulary. It was effective enough in teaching vocabulary since students in SMPN 14 Kendari had difficulties in learning English because they had lack of vocabulary and they were difficult to understand the meaning of English words. When the students wanted to accomplish a task, they needed much time to answer some questions with simple short text. The time always not enough for them because they have to find out the meaning of each word before answer the questions.

Overall, this study confirms that the use of semantic feature analysis in teaching vocabulary could give solution for teacher in increasing students' vocabulary achievement, Paulsen (2004) described that semantic feature analysis is a useful way to teach vocabulary and the students' prior knowledge or schemata will be more working on when they do the task, the process will help students to recognize the words because the students learn by themselves to finish the task based on their ideas indirectly and the teacher just provide a key answer for them and do the evaluation.

As a result, researcher found that semantic feature analysis could make students became more active in the classroom activity because there was a step where students should build their own prior knowledge so they learned by themselves. In addition, there was a discussion session in the step of semantic feature analysis it made students free to share their ideas to their friends about the assignment from teacher, as Gillies (2003) stated that students are also more motivated to achieve when working in groups as opposed to working individually. The step was really good for students in increasing their motivation in following the lesson. The students seemed to be more confident to answer any question when researcher asked them. It was because they had already discussed any ideas that they knew and did not.

Furthermore, the students also seemed to be easily to understand the reading text. It can be seen from almost of the students could answer their worksheet well based on the information that they had got from the reading text. Therefore, Jane (2012) argued that semantic feature analysis is strategy that can 
help develop learners' vocabulary. So that semantic feature analysis was a good strategy for teacher in increasing students' vocabulary achievement.

\section{CONCLUSION AND RECOMMENDATION \\ 5.1 Conclusion}

This research has presented an overview of applying semantic feature analysis strategy to improve students' vocabulary achievement. The result of this study demonstrated that there was a significant effect on Semantic Feature Analysis on students' vocabulary achievement of the second grade students of Junior High School 14 Kendari. It was proven by the obtained score of students in pre-test before they taught by using semantic feature analysis strategy. It was found the minimum score was 12.00 and the maximum score was 68.00 and mean was 29.1333. Whereas, the students' score in the post-test after being taught using semantic feature analysis strategy, the minimum score was 24.00 and the maximum score was 88.00 and mean score was 64.0000. Furthermore, the value of sig. one tailed is 0.000 which is less than the alpha value $(0.05)$ and $t_{\text {count }}$ is obtained 10.070 and higher than $t_{\text {table }}$ at the 0,05 level of significance to the line $\mathrm{df}$ $=29$ (1.699). In addition, the effect size of semantic feature analysis is 0.18 as a result. Based on Cohen's criteria the value is in small effect size, so in the other words could be concluded that $\mathrm{H}_{0}$ was rejected and $\mathrm{H}_{1}$ was accepted. Therefore, it means that there was a positive effect of semantic feature analysis strategy in improving students' vocabulary achievement.

\subsection{Recommendation}

Through the findings of this study, the researcher wrote several recommends for the next research, are:

1. This study focused on students' vocabulary achievement using semantic feature analysis strategy in Junior High School at the second grades. Therefore, the next researcher can take sample from other level such as: Senior High School level, or even in University level.

2. This study used pre-experimental one group pre-test and post-test design. Therefore, the further researcher can apply another research design, for example: Action Research or True Experimental Design, or even Quasi Experimental that uses class control.

3. The researcher focused to the students' vocabulary achievement that was integrated into reading skill. In this case, another researcher can apply this strategy in the reading skill to see the students' reading comprehension but it also should have more sources about the teaching reading using this strategy. 


\section{References}

Abdollahzadeh, Esmaeel and Amiri Nasr. 2009. The effect of Semantic Mapping as a Vocabulary Instruction Technique on EFL Learners with Different Perceptual Learning Styles. Journal of Iran University Vol.2. Retrieved on July 10, 2013 from http://cde.state.org/.

Cohen, J (1977) A coefficient of agreement for nominal scales. Educational and Psychological Measurement 20 (1), 37-46.

Edward, P. D. 1997. Developing Efficiency and Effectiveness in Teaching and Learning. USA: Longman.

Gairns, R. And Redman, S. 1986. Working with Words: A Guide to Teaching and Learning Vocabulary. USA: Cambridge University Press.

Gillies, R. M. 2003. Structuring Cooperative Group work in Classroom. International Journal of Educational Research, 39, 35-49.

Hornby. 1995. Oxford Language Dictionary. Oxford: Oxford University Press.

Jane, C. Miler. 2012. Developing Vocabulary with Adult Learners. Retrieved on July 10, 2013 from http://cde.state.org/.

Johnson, D. D. \& Pearson, P. D. 1984. Teaching Reading Vocabulary (2 ${ }^{\text {nd }}$ ed.). New York: Holt, Rinehart, and Winston.

Laufer, B. \& P. Nation. 1999. A Vocabulary Size Test of Controlled Productive Ability. Language Testing 16, 33-51.

Linse, T. Caroline. 2005. Practical English Teaching Young Learner. New York: mc Graw Hill Companies. Inc.

Marilyn, Pebbles. 2010. Academic Vocabulary. Texas: Texas University.

Nunan, D. 1999. Second Language Teaching and Learning. Boston: Heinle \& Heinle Publisher.

Paulsen, K., \& the IRIS Center. 2004. Comprehension \& Vocabulary: Grades 35. Retrieved from http://iris.peabody.vanderbilt.edu/case_studies/ICS-007.

Scrivener, Jim. 2005. Learning Teaching: A Guidebook for English Language Teachers Second Edition. Oxford: Macmillan. 
Shapiro, A. M., \& Dusty, L. W. 2005. An Investigation of the Cognitive Processes Underlying the Keyword Method of Foreign Vocabulary Learning. Language Teaching Research, 9, 133-134.

Shaw and de vet. 1980. Using Blackboard Drawing. England: Heineman.

Spratt, Mary., et al. 2005. The Teaching Knowledge Test Course. Cambridge: University of Cambridge.

Sugiyono. 2008. Metode Penelitian Kualitatif dan R\&D. CV. Alfabeta, Bandung.

Sveconis, Daniel J. and Stephen Kerst. 2006. Investigating the Teaching of Second Language Vocabulary through Semantic Mapping in a Hypertext Environment. Catholic University, Washington DC, America. The Internet TESL Journal. Vol.12 No. $2 \& 3$ http://calico.org/.

Taylor, D. Bruce, Maryann Mraz, William D., Robert J., Karen D. 2009. Using Explicit Instruction to Promote Vocabulary Learning of Struggling Readers. North Carolina University, North Carolina, USA. The Internet TESL Journal. Vol. X No. 10 http://uncc.org/.

Thornbury, Scott. 2002. How to Teach Vocabulary. Series Editor: Jeremy Harmer. Malaysia: Longman.

Travers, John P. 1970. Fundamentals of Educational Psychology. Scrantom, Pensylvania: International Textbook Company.

Ur, Penny. 1996. A Course of Language Teaching. Cambridge: Cambridge University Press.

Vellis, De. 2003. Focus on Research Methods is the CVI an Acceptable Indicator of Content Validity. 2007 Wiley Periodicals, Inc. Appraisal and Recommendations. Research in Nursing \& Health, 2007, 30, 459-467. 